\title{
Epibiont occurrence on gastropod shells used by the hermit crab Loxopagurus loxochelis (Anomura: Diogenidae) on the northern coast of São Paulo, Brazil
}

\author{
Luciane Ayres-Peres ${ }^{1} \&$ Fernando L. Mantelatto ${ }^{1,2}$
}

\author{
${ }^{1}$ Laboratório de Bioecologia e Sistemática de Crustáceos, Departamento de Biologia, Faculdade de Filosofia, Ciências e Letras \\ de Ribeirão Preto, Universidade de São Paulo. Avenida Bandeirantes 3900, 14040-901 Ribeirão Preto, São Paulo, Brazil. \\ ${ }^{2}$ Corresponding author. E-mail: flmantel@usp.br
}

\begin{abstract}
Gastropod shells occupied by hermit crabs are an important attachment substrate for epifauna, and these shells are often damaged. The present study aimed to characterize the epibionts and extent of damage for gastropod shells occupied by the hermit crab Loxopagurus loxochelis (Moreira, 1901). Samples were collected monthly over a period of one year (from July 2002 through June 2003), in the Caraguatatuba and Ubatuba regions, on the northern coast of São Paulo, Brazil. The sampling was performed using a fishing boat equipped with double-rig nets. The shells were identified and weighed. Loxopagurus loxochelis occupied 14 gastropod shell species in Caraguatatuba and five in Ubatuba. In the two areas, approximately $55 \%$ of these gastropod shells bore epibionts, and a significantly large number $(p<0.05)$ showed no damage. The presence of epibionts did not significantly change the mean weight of shells. This cover may provide camouflage to the animals when they are associated with the sandy substrate, which possibly affects the occupancy of the shells by the hermit crabs. Undamaged shells may reflect a high availability of shells in good condition in the environment.
\end{abstract}

KEY WORDS. Crustacea; Decapoda; exobiont; incrustation.

Because of the physical characteristics of water, in the aquatic environment - even for consumers - a sessile mode of life is possible (food vector water) and often favorable (reduced risk of dislodgement) (WAHL 1997). In the aquatic realm, tens of thousands of species representing most of the marine phyla have adopted this mode of life for at least one ontogenetic phase: many bacteria, protozoa and diatoms, most macroalgae, all sponges, most cnidarians, many mollusks (bivalves and gastropods), some rotifers, most bryozoans, most phoronids, many brachiopods, many tube-building polychaetes, some echinoderms, a few crustaceans (e.g. Cirripedia), some hemichordates, and all ascidians (WAHL \& MARK 1999).

By definition "epibionts" are organisms growing attached to a living surface. Trophic exchange with the substrate organism, if present, is facultative. "Basibiont" is the substrate organism, which is the host to the epibiont. Accordingly, "epibiosis" is a non-symbiotic, facultative association between epibionts and basibiont (WAHL 1989).

Gastropod shells occupied by hermit crabs are an important attachment substrate for epifauna in many predominantly soft-bottom benthic communities (BROOKS \& MARISCAL 1986). The ability of hermit crabs to select, occupy, and carry gastropod shells or some other hard protective structure is one of the most notable characteristics of the group and one of the principal reasons for their evolutionary success (CONOver 1978,
Garcia \& Mantelatto 2001). The close association between the hermit crabs and their adopted shelter strongly influences almost all aspects of their biology (HAZLETT 1981).

The rate at which these shells become available is very slow and directly dependent on the mollusk life cycle and abundance, especially their reproduction and mortality rates (Meireles et al. 2003). Besides this, shells are available for the hermit crabs only for short periods before they become eroded, buried, broken (SPIght 1985), or used by other hermits.

There is strong evidence that hermit crabs do not randomly enter into gastropod shells, but rather choose them according to the species and characteristics associated with the shape, coverage, dimension, and shell weight (Grant \& UlmER 1974), as well as the availability of the shelters in nature (Meireles et al. 2003). In this context, the presence of epibionts on the resource (gastropod shell) is one factor that can influence the shell selection by hermit crabs. According to CoNOver $(1976,1979)$, there is a significant difference between the epifauna of empty shells in the environment and shells with hermit crabs; besides the biomass, the number of epifaunal species and the dominant symbiotic species population per shell, increase with the increase in shell weight.

Desiccation and other non-destructive causes (e.g. parasitism) may leave the shells intact, while predation may completely destroy them (see TURRA et al. 2005 for an extensive re- 
view). The different species of shell-breaking predators and predatory strategies produce types of damage to gastropod shells (Bertness \& Cunningham 1981, McLean 1983, Lau 1987) that allow their future use by hermit crabs (TurRa et al. 2005).

In view of the gap that exists in the Brazilian literature regarding studies on the epibiont fauna that occurs on the surface of shelter gastropod shells used by hermits - among the few studies from shallow/intertidal waters are those of Creed (2000) and TURRA (2003) - and the state of preservation of shells (Turra 2003, Turra et al. 2005), we studied the external gastropod shell coverage (by invertebrates), comparing the presence and types of epibionts on the shells that are most frequently used by the endemic Southern Atlantic hermit crab Loxopagurus loxochelis (Moreira, 1901). We also evaluated the conditions of conservation of shells used by this species.

\section{MATERIAL AND METHODS}

The collections were made monthly from July 2002 through June 2003, with a shrimp fishing boat equipped with double trawling nets, in the areas of Caraguatatuba (23 $36^{\circ} 09^{\prime \prime}$ $23^{\circ} 40^{\prime} 12^{\prime \prime} \mathrm{S}$ and $45^{\circ} 07^{\prime} 16^{\prime \prime}-45^{\circ} 25^{\prime} 35^{\prime \prime} \mathrm{W}$ ) and Ubatuba $\left(23^{\circ} 26^{\prime} 08^{\prime \prime}-23^{\circ} 31^{\prime} 57^{\prime \prime} \mathrm{S}\right.$ and $\left.44^{\circ} 55^{\prime} 28^{\prime \prime}-45^{\circ} 03^{\prime} 18^{\prime \prime} \mathrm{W}\right)$, northern coast of São Paulo, Brazil. After collection, the hermit crabs were immediately frozen. In the laboratory, the animals were carefully removed from their shells.

The gastropod shell species collected were identified according to Rios (1994). The presence of epibionts in relation to the gastropod shell species used by L. loxochelis was evaluated. The species of macroinvertebrates comprising this community of epibionts were identified to the lowest possible level. Only one qualitative measurement (presence/absence) was made, with no reference to the position of the epibionts on the shell surface. This was done because almost all the surfaces of the shells are totally covered by epibionts, with no possibility to describe the exact limits of the incrustation.

All the shells (with and without epibionts, i.e., the shells were weighed in the same condition that they were collected, and the epibionts were not removed from the shells prior to this process) were weighed (shell dry weight $-\mathrm{SDW}, 24 \mathrm{~h}$ at $60^{\circ} \mathrm{C}$ ).

The frequency of damaged (broken) shells used by $L$. loxochelis in the two areas was also analyzed using the $\chi^{2}$ test, to evaluate if the animals used the better-preserved or broken shells in the environment. Only the presence or absence of shell damage was considered, such as loss of a piece of shell from the aperture, small cracks, etc.

The variation in the shell weight due to the natural presence/absence (without removing the cover on the external surface) of epibionts was evaluated by ANOVA on Ranks (ZAR 1996).

Hermit crab specimens were preserved in $80 \%$ ethyl alcohol and were deposited in the Crustacean Collection of the Department of Biology (CCDB/FFCLRP/USP) under catalogue numbers 1485 to 1514 .

\section{RESULTS}

In total, 492 specimens of $L$. loxochelis were collected: 366 in Caraguatatuba, occupying 14 gastropod shell species Buccinanops deformis (King \& Broderip, 1832), Buccinanops gradatum (Deshayes, 1844), Chicoreus tenuivaricosus (Dautzenberg, 1927), Conus clerii Reeve, 1844, Cymatium parthenopeum (von Salis, 1793), Dorsanum moliniferum (Valenciennes, 1834), Fusinus brasiliensis (Grabau, 1904), Olivancillaria urceus (Röding, 1798), Phalium granulatum (Born, 1778), Polinices hepaticus (Röding, 1798), Polinices lacteus (Guilding, 1834), Prunum martini (Petit, 1853), Stramonita haemastoma (Linnaeus, 1767), and Tonna galea (Linnaeus, 1758) - and 126 in Ubatuba, with five gastropod species - Agaronia travassosi (Morretes, 1938), B. gradatum, C. parthenopeum, O. urceus, and S. haemastoma.

Of the 14 gastropod shell species used in Caraguatatuba, three showed high occupation percentages: B. gradatum (53.85\%), O. urceus (31.32\%), and S. haemastoma (8.52\%); and in Ubatuba, two of the five species together were occupied by over $90 \%$ of the crabs: B. gradatum (30.16\%) and O. urceus (63.5\%).

In Caraguatatuba, two hermit crabs were found without shells. Of the total $(\mathrm{n}=364)$ analyzed shells, $54.94 \%(\mathrm{n}=200)$ had epibionts covering the outer surface. These were classified as: bryozoans (Conopeum spp. and Ascophora spp.), barnacles (Octalasmis spp. and Balanus spp.), bivalve mollusks (Chama spp.), polyplacophorans (Ischnochiton spp.), and polychaete worm tubes (Sabellidae). In Ubatuba, more than half of the shells occupied by L. loxochelis were also encrusted by epibionts $(57.30 \%, \mathrm{n}=$ 149): anemones (Anthozoa, Calliactis sp.), bryozoans, barnacles, mollusks, and polychaete worm tubes (Fig. 1). In both areas, some shells with more than one group of epibionts were recorded. No significant difference was observed between the occupation of shells with epibionts and the sex of the hermit crabs (males occupied $49.1 \%$ and females $63.1 \%$ of gastropod shells with epibionts, $\mathrm{p}>0.05$ ).

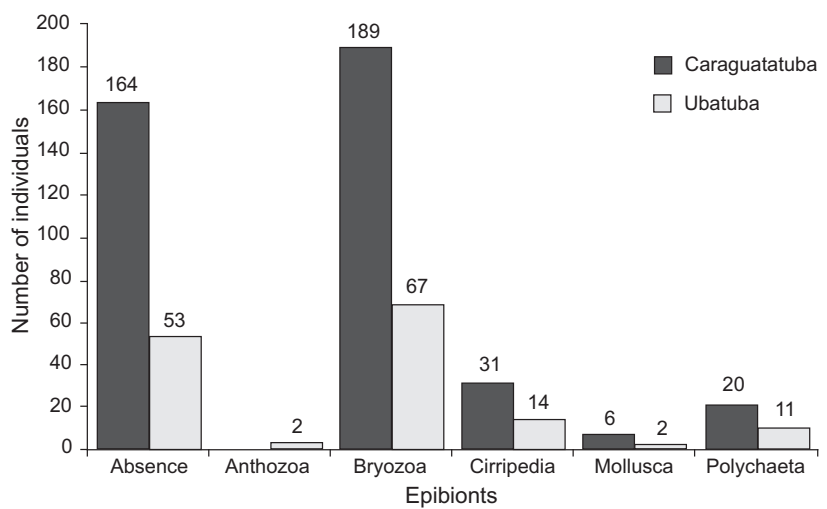

Figure 1. Epibionts found on gastropod shells occupied by $L$. loxochelis in Caraguatatuba and Ubatuba, from July 2002 through June 2003. Numbers above bars = number of individuals; Absence $=$ shells without epibionts. 
Of the total of shells occupied by hermit crabs, a significantly large number (260 shells, $\chi^{2}=66.85, \mathrm{p}<0.05$ in Caraguatatuba; and 108 shells, $\chi^{2}=10.28, p<0.05$ in Ubatuba) was found to be damaged. This pattern was confirmed for the most of the species occupied.

The presence of epibionts, when compared to the shells without epibionts, did not affect the mean weight of the three most-occupied shells from Caraguatatuba and Ubatuba (Tab. I). An increase in weight was not observed in the shells covered by epibionts. However, the mean weight when analyzed for the total of occupied shells, showed a significant increase in their weight in the Ubatuba population only. Although we did not test this perception, while manipulating the specimens we observed that the shells thickly covered with epibionts were more fragile than the uninfested ones.

Bryozoans were the most frequent epibionts in the three most occupied species of gastropods in Caraguatatuba, followed by barnacles (Cirripedia). In Ubatuba, B. gradatum shells showed a low percentage of individual infestation by epibionts, a different pattern than that observed for O. urceus, where the majority of the shells were encrusted by bryozoans (Figs 2 and 3).
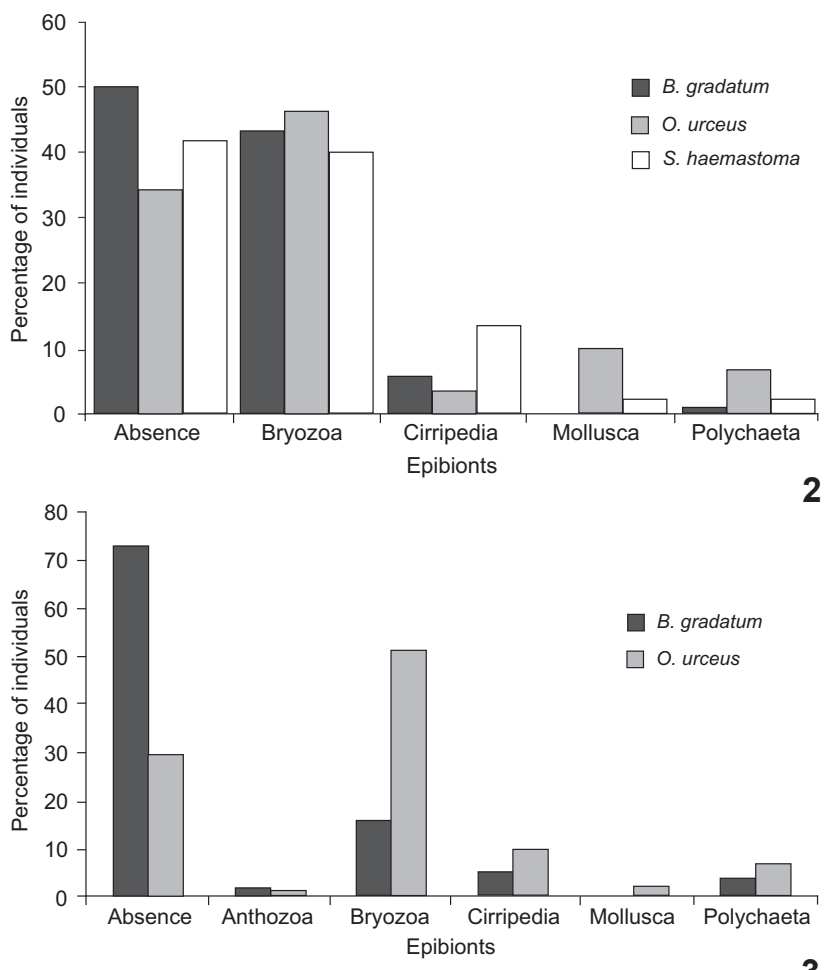

Figures 2-3. Epibionts found on the gastropod shell species ( $B$. gradatum, $\mathrm{O}$. urceus, and $\mathrm{S}$. haemastoma) that were most often occupied by L. loxochelis in (2) Caraguatatuba and (3) Ubatuba, São Paulo, from July 2002 through June 2003. Absence = shells without epibionts.

\section{DISCUSSION}

In both areas studied, a large proportion of shells used by L. loxochelis were encrusted by epibionts, the majority by bryozoans, followed by barnacles and polychaete worm tubes. The presence of these epibionts did not alter the weight of the shells, where a difference was observed only in the total shell number in Ubatuba, in that there was an increase in the shell weight with epibionts. However, when the most occupied species were evaluated, significant differences were not found.

Considering that the epibionts were not removed from the shells to obtain their weights, we can assume that the shells with epibionts are lighter than the shells without them, and their loss of weight may be counterbalanced in some situations (depending on the epibiont) by the presence of epibionts. In the present study, the main epibiont found was bryozoans, which leads us to assume that they did not add much weight to the shells.

Thousands of epibiotic associations comprising a substrate organism (basibiont) and one or several attached species (epibionts) have been reported from marine and freshwater habitats (WAHL \& MARK 1999). The presence or absence of certain species of epifauna influences the probability that a hermit crab will occupy a shell, as well as altering the preference of hermit crabs for certain shells (CONOvER 1979). Additionally, many symbionts have a greater probability of surviving if they are associated with a hermit crab, usually due to an increase in food resources and protection against predators. Nevertheless, hermit crabs occupy gastropod shells with epibionts by a passive process, and according to selection experiments, the animals did not select shells based on their epibionts (HAzLETT 1984).

Shell epibionts may aid hermit crab protection against predators (TURRA 2003). Hermit crabs have generally gained less from their relationships with symbionts than their associates, but in many regions they must inhabit shells with these associates because of a limited supply of empty shells. However, encrusting organisms such as cnidarians and bryozoans or symbiosis with members of Anthozoa (actinians and zoanthids) that can produce pseudoshell may extend the shell apertures and thereby reduce or eliminate the need for hosts to find new shells, a benefit with clear consequences for fitness (WiLliams \& McDermott 2004, Schejter \& Mantelatto 2010).

Martinelli \& Mantelatto (1998), in their study with $L$. loxochelis in the Ubatuba region, found that epibionts were frequent on $O$. urceus gastropod shells, but were absent from $B$. gradatum, the two most occupied shells. In Caraguatatuba, the three most occupied species of shells showed similar encrustation patterns by epibionts, but in Ubatuba, B. gradatum shells showed a lower infestation rate in relation to O. urceus. The shell species characteristics indirectly affect the epifaunal community because the hermit crabs do not choose the shells randomly in the natural environment (CONOver 1979), nor in laboratory conditions (BIAGI et al. 2006). 
Table I. Mean dry weight ( $\mathrm{g}$ ) and standard deviation of the three species of gastropod shells that were most often occupied by L. loxochelis, with and without epibionts (without removing the cover on the outer surface), collected in Caraguatatuba and Ubatuba, from July 2002 through June 2003. ( $\left.{ }^{*}\right)$ Significant difference, ANOVA, $\mathrm{p}<0.05$.

\begin{tabular}{lcccccc}
\hline \multirow{2}{*}{ Shell } & \multicolumn{2}{c}{ Mean dry weigh without epibionts } & & \multicolumn{3}{c}{ Mean dry weigh with epibionts } \\
\cline { 2 - 3 } \cline { 5 - 6 } & Caraguatatuba & Ubatuba & & Caraguatatuba & Ubatuba \\
\hline B. gradatum & $3.64 \pm 3.70$ & $4.12 \pm 4.70$ & & $3.66 \pm 3.74$ & $9.10 \pm 4.77$ \\
O. urceus & $8.56 \pm 3.60$ & $9.26 \pm 4.57$ & & $8.05 \pm 3.74$ & $9.42 \pm 4.55$ \\
S. haemastoma & $4.78 \pm 3.91$ & & & $6.19 \pm 3.75$ & - \\
\hline Total of shells & $4.93 \pm 3.72$ & $6.51 \pm 4.57^{*}$ & & $5.56 \pm 3.72$ & $8.30 \pm 4.55^{*}$ \\
\hline
\end{tabular}

Bryozoans, barnacles, polychaete worm tubes, and cnidarians are frequent and particular cases of epibionts with hermit crabs, as reported by Pessani \& Premoli (1993) studying Cestopagurus timidus (Roux, 1830); Martinelli \& Mantelatto (1998) with L. loxochelis; Bertini \& Fransozo (2000) in a study with the hermit crab Petrochirus diogenes (Linnaeus, 1758); McDermotт (2001), analyzing the presence of numerous ectoand endosymbionts in Pagurus longicarpus Say, 1817; and Teross et al. (2006) in Pagurus exilis (Benedict, 1892). In the same region, a similar pattern of epibiosis was found for Dardanus insignis (Saussure, 1858), where bryozoans, polychaete tubes, barnacles, and mollusks (generally bivalves) occurred in high frequencies on the gastropod shells; cnidarians (sea anemones, corals), algae and polyplacophore mollusks (chitons) occurred in low frequencies (Meireles \& Mantelatto 2008).

Although all these hermit species exhibit a variety of external epibionts, their response to the percentage of infestation by each group differed. Analogously, in live bivalves (scallops) from deep areas, the most common organisms found in association were polychaetes, other bivalves, and crustaceans (barnacles, amphipods, and isopods), as well as bryozoans and ascidians (SCHEJTER \& BREMEC 2007). This scenario evidenced the high plasticity regarding the mechanism and pattern of epibiosis in relation to the substrate (host) and habitats among hermit crab faunas. A more complete set of studies with species from other areas is needed for a comprehensive examination of this theme. The outcome of the present study should encourage future analysis of epibiosis in congeners.

In agreement with Martinelli \& Mantelatto (1998), the occupation by L. loxochelis of gastropod shells with large numbers of bryozoans is probably related to a high incidence of this epibiont in the environment. It is plausible that this encrustation may camouflage the crabs in the sand, possibly affecting the crab' choice and occupation of shells. Also, in some cases this association may be related to the shell-like morphology acquired by the epibionts, which can increase the shell strength and/or size (Brooks \& GwaLtney 1993, SANDFord 2003). The occupation of colonized shells can potentially minimize predation levels, increase fitness and predation, and reduce competition with other shell-seeking hermit crabs (ВRоокs \& Mariscal 1985, Buckley \& Ebersole 1994). However, certain her- mit crabs still prefer bare shells to those colonized by hydroids. According to WAHL \& MARK (1999), basibionts (shells of hermit crabs) may benefit from the presence of epibionts due to effects such as optical and chemical camouflage, reduced friction, protection against desiccation and harmful irradiation, or associational defense. Because hard substratum is often limited, epibiosis provides the epibiont with this valuable resource. When epibiosis-related effects are neutral or positive for a basibiont species and beneficial for the epibiont species, selection should favor the evolution of active attraction by the basibiont and/or settlement specificity of the epibiont species.

Damaged shells were occupied in small and insignificant proportions, evidence that confirms the high availability of shells in this region (Meireles \& Mantelatto 2008) for the local hermit crab population. Additionally, laboratory experiments have demonstrated interesting abilities of $L$. loxochelis to select shells according to their size, volume, weight, and condition (BIAGI et al. 2006). Utilization of intact shells by hermit crabs may be a consequence of predatory events involving crabs and their relatively large-sized prey, but may also be a consequence of stochastic mortality pulses (TurRa et al. 2005).

The puzzling association between hermit crabs, shells, and epibionts, with the reported cost/benefit ratio and possible mutual advantages, this relationship between the hermit crab, gastropod shells, and the epibiont can be classified as a non-specific and non-obligate association that might also be related to other factors such as the gastropod life cycle and the diversity of invertebrate fauna in the region. In addition, the interaction, if any, among more than one species of invertebrate when they co-occur on the same shells is totally unknown. In conclusion, we assume that $L$. loxochelis may prefer to occupy bare shells over incrusted ones. On the other hand, we believe that hermit crabs can choose shells in good condition, and this preference may reflect several factors such as the differential selection of well-preserved shells by L. loxochelis, and may also be related to the mortality pulses of the gastropods.

Experimental studies to evaluate if the hermit crabs make an active choice concerning the presence or absence and type of epibiont on the shells, and also if the hermit crabs actively select the more intact shells, may help in understanding the relationship of these animals to the resources that they use. 


\section{ACKNOWLEDGEMENTS}

This research is part of a Master's dissertation by LAP, and was supported by CAPES. FLM received support from the CNPq for an ongoing Research Fellowship. Special thanks are due to those people who collaborated during the development of this study: Adilson Fransozo (UNESP) for support and facilities during sampling collections provided by FAPESP - Biota Program (Proc. 98/01090-3); to all NEBECC colleagues and to members of the Laboratory of Bioecology and Crustacean Systematics of FFCLRP/USP who helped with sampling; to the Postgraduate Program in Comparative Biology of FFCLRP/USP and the Centro de Biologia Marinha (CEBIMar/USP) for assistance and facilities during field work; to Marcelo Scelzo (University of Mar del Plata) and Roberto Shimizu (IB/USP) for suggestions made during the dissertation defense; to Renata Biagi for comments on the first version of this manuscript; to the people that identified some of the epibiont fauna: Álvaro Migotto (CEBIMar/USP) for the anemone species, Fabio Pitombo (UFRJ) for the barnacles, Rosana Rocha (UFPR) for the bryozoans, and Osmar Domaneschi (IB/ USP) and Wagner Avelar (FFCLRP/USP) for mollusks; and to an anonymous reviewer for suggestions and contributions toward the improvement of this paper. Janet W. Reid (JWR Associates, USA) revised the English text. All experiments conducted in this study comply with current applicable state and federal laws.

\section{LITERATURE CITED}

Bertini, G. \& A. Fransozo. 2000. Patterns of shell utilization in Petrochirus diogenes (Decapoda, Anomura, Diogenidae) in the Ubatuba region, São Paulo, Brazil. Journal of Crustacean Biology 20 (3): 468-473.

Bertness, M.D. \& C. Cunningham. 1981. Crab shell-crushing predation and gastropod architectural defense. Journal of Experimental Marine Biology and Ecology 50 (2-3): 213230.

Biagi, R.; A.L. Meireles; M.A. Scelzo \& F.L. Mantelatto. 2006. Comparative study of shell choice by the southern endemic hermit crab Loxopagurus loxochelis from Brazil and Argentina. Revista Chilena de Historia Natural 79 (4): 481-487.

Brooks, W.R. \& C.L. Gwaltney. 1993. Protection of symbiotic cnidarians by their hermit crab hosts: Evidence for mutualism. Symbiosis 15 (1): 1-13.

Brooks, W.R. \& R.N. Mariscal. 1985. Shell entry and shell selection of hydroid-colonized shells by three species of hermit crabs from the northern Gulf of Mexico. Biological Bulletin 168 (1): 1-17.

BROOKS, W.R. \& R.N. MaRISCAL. 1986. Interspecific competition for space by hydroids and a sea anemone living on gastropod shells inhabited by hermit crabs. Marine Ecology Progress Series 28 (1): 211-244.

Buckley, W.J. \& J.P. Ebersole. 1994. Symbiotic organisms increase vulnerability of a hermit crab to predation. Journal of Experimental Marine Biology and Ecology 182 (1): 49-64.
Conover, M.R. 1976. The influence of some symbionts on the shell-selection behavior of the hermit crabs, Pagurus pollicaris and Pagurus longicarpus. Animal Behaviour 24 (1): 191-194.

CONOVER, M.R. 1978. The importance of various shell characteristics to the shell - selection behavior on the hermit crabs. Journal of Experimental Marine Biology and Ecology 32 (2): 131-142.

Conover, M.R. 1979. Effect of gastropod shell characteristics and hermit crabs on shell epifauna. Journal of Experimental Marine Biology and Ecology 40 (1): 81-94.

Creed, J.C. 2000. Epibiosis on cerith shells in a seagrass bed: correlation of shell occupant with epizoite distribution and abundance. Marine Biology 137 (5-6): 775-782.

Garcia, R.B. \& F.L. Mantelatto. 2001. Shell selection by the tropical hermit crab Calcinus tibicen (Herbst, 1791) (Anomura, Diogenidae) from Southern Brazil. Journal of Experimental Marine Biology and Ecology 265 (1): 1-14.

Grant, W.C. \& K.M. Ulmer. 1974. Shell selection and aggressive behavior in two sympatric species of hermit crabs. Biological Bulletin 146 (1): 32-43.

Hazlett, B.A. 1981. The behavioral ecology of hermit crabs. Annual Review of Ecology and Systematics 12 (1): 1-22.

Hazlett, B.A. 1984. Epibionts and shell utilization in two sympatric hermit crabs. Marine Behaviour and Physiology 11 (2): 131-138.

LAU, C.J. 1987. Feeding behavior of the Hawaiian slipper lobster, Scyllarides squammosus, with a review of decapod crustacean tactics on molluscan prey. Bulletin of Marine Science 41: 378-391.

Martineli, J.M. \& F.L. Mantelatto. 1998. Occurrence of exobionts in gastropod shells occupied by the hermit crab Loxopagurus loxochelis (Anomura: Diogenidae) in Ubatuba Bay (SP) Brazil. Anais do IV Simpósio de Ecossistemas Brasileiros 2 (104): 221-226 [Publicações ACIESP].

McDermott, J.J. 2001. Symbionts of the hermit crab Pagurus longicarpus Say, 1817 (Decapoda: Anomura): New observations from New Jersey waters and a review of all known relationships. Proceedings of the Biological Society of Washington 114 (3): 624-639.

McLEAN, R. 1983. Gastropod shells - a dynamic resource that helps shape benthic community structure. Journal of Experimental Marine Biology and Ecology 69 (2):151-174.

Meireles, A.L.; R. Biagi \& F.L. Mantelatto. 2003. Gastropod shell availability as a potential resource for the hermit crab infralittoral fauna of Anchieta Island (SP), Brazil. Nauplius 11 (2): 99-105.

Meireles, A.L. \& F.L. Mantelatto. 2008. Biological features of a puzzling symbiotic association between the hermit crab Dardanus insignis and the porcellanid crab Porcellana sayana (Crustacea). Journal of Experimental Marine Biology and Ecology 362 (1): 38-42.

Pessani, D. \& C. Premoli. 1993. Some aspects of the biology of Cestopagurus timidus (Crustacea, Paguridae) in relation to the occupied shell. Bollettino di Zoologia 60 (2): 199-206. 
Rios, E.C. 1994. Seashells of Brazil. Rio Grande, Fundação Universidade de Rio Grande, Instituto Acqua, Museu Oceanográfico de Rio Grande, $2^{\text {nd }}$ ed., $368 p$.

SANDFORD, F. 2003. Population dynamics and epibiont associations of hermit crabs (Crustacea: Decapoda: Paguroidea) on Dog Island, Florida. Memoirs of Museum Victoria 60 (1): 45-52.

Schejter, L. \& C.S. Bremec. 2007. Epibionts on Flexopecten felipponei (Dall, 1922), an uncommon scallop from Argentina. American Malacological Bulletin 22 (1-2): 75-82.

SChejter, L. \& F.L. Mantelatto. 2010. Shelter association between the hermit crab Sympagurus dimorphus and the zoanthid Epizoanthus paguricola in the southwestern Atlantic Ocean. Acta Zoologica 91 (2) [DOI: 10.1111/j.1463-6395.2009.00440.x].

Spight, T.M. 1985. Why small hermit crabs have large shells. Researches on Population Ecology 27 (1): 39-54.

Terossi, M.; D.L.A. Espósito; A.L. Meireles; R. Biagi \& F.L. Mantelatto. 2006. Pattern of shell occupation by the hermit crab Pagurus exilis (Anomura, Paguridae) on the northern coast of São Paulo State, Brazil. Journal of Natural History 40 (1-2): 77-87.

TURRA, A. 2003. Shell condition and adequacy of three sympatric intertidal hermit crab populations. Journal of Natural History 37 (15): 1781-1795.

Turra, A.; M.R. Denadai \& F.P.P. Leite. 2005. Predation on gastropods by shell-breaking crabs: effects on shell availability to hermit crabs. Marine Ecology Progress Series 286 (1): 279-291.

WAHL, M. 1989. Marine epibiosis. I. Fouling and antifouling: some basic aspects. Marine Ecology Progress Series 58 (1): 175-189.

WAHL, M. 1997. Living attached: aufwuchs, fouling, epibiosis, p. 31-83. In: R. Nagabhushanam \& M.F. Thompson (Eds). Fouling organisms of the Indian Ocean: biology and control technology. Rotterdam, A.A. Balkema, 538p.

WAHL, M. \& O. MARK. 1999. The predominantly facultative nature of epibiosis: experimental and observational evidence. Marine Ecology Progress Series 187 (1): 59-66.

Williams, J.D. \& J.J. McDermott. 2004. Hermit crab biocoenoses: a worldwide review of the diversity and natural history of hermit crab associates. Journal of Experimental Marine Biology and Ecology 305 (1): 1-128.

ZAR, J.H. 1996. Biostatistical Analysis. Upper Saddle River, Prentice-Hall, 907p.

Submitted: 03.VI.2009; Accepted: 06.II.2010.

Editorial responsibility: Paulo da Cunha Lana 